\title{
Hematopoietic stem cell transplantation complicated with EBV associated hemophagocytic lymphohistiocytosis in a patient with DOCK2 deficiency
}

\author{
Elif Soyak Aytekin ${ }^{1 \oplus}$, Deniz Çağdaş ${ }^{1 \oplus}$, Çağman $\operatorname{Tan}^{1 \oplus}$, Büşranur Çavdarlı ${ }^{2 \oplus}$ \\ Işıl Bilgiçَ̧ై İlhan Tezcan $^{1 \oplus}$ \\ ${ }^{1}$ Division of Pediatric Immunology, ${ }^{3}$ Department of Pediatrics, Hacettepe University Faculty of Medicine, Ankara; ${ }^{2}$ Department of \\ Medical Genetics, Ankara Bilkent City Hospital, Ankara, Turkey.
}

\begin{abstract}
Background. Dedicator of cytokinesis 2 (DOCK2) deficiency is a rare autosomal recessive combined immunodeficiency presenting with very early onset, severe bacterial and viral infections. In DOCK2 deficiency; $\mathrm{T}, \mathrm{B}$ and NK cell numbers are decreased and functions are impaired resulting in severe atrophy of secondary lymphoid tissues. The aim of this report is to provide information on clinical and laboratory features and hematopoietic stem cell transplantation (HSCT) outcomes of a DOCK2 deficient patient. The patient was diagnosed by using a targeted next generation sequencing primary immunodeficiency (PID) panel. Lymphocyte subsets were measured by flow-cytometry.

Case. Here, we describe a patient with DOCK2 deficiency presented with severe combined immunodeficiency. He underwent HSCT without conditioning regimen before the genetic diagnosis and developed hemophagocytic lymphohistiocytosis(HLH) due to Epstein-Barr virus (EBV) infection.
\end{abstract}

Conclusions. Genetic testing is necessery for early diagnosis of DOCK2 deficiency. The curative treatment should be HSCT soon after diagnosis.

Key words: DOCK2 deficiency, hemophagocytic lymphohistiocytosis, hematopoietic stem cell transplantation, severe combined immune deficiency, EBV associated hemaphagocytic lymphohistiocytosis.

Dedicator of cytokinesis 2 (DOCK2) deficiency is a rare autosomal recessive combined immunodeficiency presenting with very early onset, severe bacterial and viral infections. It is caused by homozygous or compound heterozygous mutations in the DOCK2 gene. The curative treatment is hematopoietic stem cell transplantation (HSCT) soon after diagnosis.

DOCK2 protein is predominantly expressed in hematopoietic cells and regulates leukocyte activation/migration by stimulating and activating Rac. Rac is a small signaling G

$凶$ Deniz Çă̆daş

deniz.ayvaz@hacettepe.edu.tr

Received 17th December 2020, revised 14th March 2021, accepted 9th May 2021. protein, which is a subfamily of the Rho family of GTPases. T and B cell migration to peripheral lymph node is mediated by CCL21, CXCL12 and CXCL13, homeostatic chemokines expressed in high endothelial venules and stromal cells. It is shown that in vitro stimulation of DOCK2deficient (DOCK2(-/-)) $\mathrm{T}$ and $\mathrm{B}$ cells with CCL21, CXCL12 and CXCL13 do not stimulate chemotactic response leading to severe atrophy of secondary lymphoid tissues. ${ }^{1,2}$

$B$ and NK cell functions are impaired in addition to $\mathrm{T}$ cell number/function defects in DOCK2 deficiency. Sanui et al. ${ }^{3}$ showed that TCR-mediated Rac activation was almost totally abolished in (DOCK2-/-) cells. DOCK2 regulates $\mathrm{T}$ cell activation through Rac protein activation to provide immunological synapse formation. ${ }^{3}$ Rac activation is impaired in plasmacytoid 
dendritic cells similar to lymphocytes in DOCK2 deficiency, resulting in the reduction of motility and the loss of polarity during chemotaxis. Recently Moens et al. ${ }^{4}$ showed that reactive oxygen species production are also partially impaired in DOCK2-deficient neutrophils.

As far as we know only 11 patients were

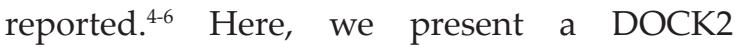
deficient patient who underwent HSCT without conditioning regimen and died because of Candida pneumonia after EpsteinBarr virus (EBV) associated hemophagocytic lymphohistiocytosis (HLH).

\section{Case Report}

A one-year-old boy was admitted to Hacettepe University Ihsan Dogramaci Children's Hospital with recurrent diarrhea. He had a normal birthweight, received vaccination according to the routine immunization schedule. During the follow-up period, he had been hospitalized once due to perianal abscess and three times for pneumonia, including Cytomegalovirus (CMV) pneumonia at 4.5 months of age. His parents were consanguineous (first-degree cousins) and had a four-year-old healthy sister.

On physical examination, his body weight was $12 \mathrm{~kg}$ (50-75 percentiles (p)), height, 74 $\mathrm{cm}(<3 p)$, head circumference, $46,5 \mathrm{~cm}(25 \mathrm{p})$. He had hepatosplenomegaly (both $4 \mathrm{~cm}$ below the costal margin).

Laboratory tests showed normal total lymphocyte count (8400/mm3 (3200-12300)), normal immunglobulin levels (IgA:79,7mg/ dl (17-69)), IgG:2880mg/dl (463-1006), IgM:51,9mg/dl (46-159)) with low CD3 (31\% (53-75)), CD4 (8\% (32-51)), normal CD16/56 (4\% (3-15)) and high CD19 (65\% (16-35)) ratio and very low naive CD4+ T cells $(0.2 \%$ (57.1-84.9)), naive CD8+ T cells (0.4\% (28.4-80.6)) and recent thymic emigrants (1\% (31-81)), suggestive of severe combined immunodeficiency. Monthly intravenous immunoglobulin (IVIG) treatment $(400 \mathrm{mg} / \mathrm{kg} /$ dose $)$, trimethoprim sulfamethoxasole and fluconazol prophylaxis were started. At 14 months of age, HSCT (6,6X108nucleated cells/kg) was performed from his HLA-identical father without any conditioning regimen. He was discharged three weeks after HSCT as he was well and an increase in CD3 after HSCT compatible with engraftment was recorded.

After receiving the informed consent from the parents, next-generation sequencing (NGS) primary immunodeficiency (PID) panel of 266 genes (Thermofischer-Ion Torrent Platform) was performed on the patient and a homozygous DOCK2 mutation (NM_004946.2 c.1773_1774insG) (p.L592Afs*76) was found. The mutation was novel, not found in the healthy population (Gnomed, 1000G). Mutation taster predicts that the variant is disease-causing (CADD_Score:35). This is a null variant that causes a frameshift defect. The probability of being loss-of-function intolerant (pLI) score of the DOCK2 gene indicates that the gene function is not tolerant for loss-of-function variants. The c.1773_1774insG variant is classified as a pathogenic causative variant for the disease according to the American College of Medical Genetics and Genomics 2015 guidelines. ${ }^{7}$ The variant was detected as a heterozygous state in the parents by another NGS platform (MiseqIllumina San Diego, CA) using PCR primers designed in-house and was visualized with ALAMUT® VISUAL (Interactive Biosoftware: France) software. We gave genetic counseling to the parents. Although there were other consanguineous marriages in the family, our patient was the only affected person.

Three months after HSCT, the patient was admitted to another center with a swelling on the neck. Physical examination revealed cervical lymphadenopathy, massive hepatosplenomegaly $(6 \mathrm{~cm}$ and $9 \mathrm{~cm}$ below the costal margins respectively), and maculopapular rash on arms and trunk. As the skin biopsy was compatible with grade 1 graft versus host disease, cyclosporine was started. We did an extensive infection workup. It included blood 
cultures, polymerase chain reaction (PCR) testing for mycobacteria and Herpes family, respiratory viruses, and parvovirus. EpsteinBarr Virus viremia (EBV DNA, 991 copies/mL) was present, and acyclovir was started. Despite the broad-spectrum antibiotic therapy, the fever continued, and the patient was evaluated for hemophagocytic lymphohistiocytosis (HLH). Anemia (hemoglobin:7,8g/dl) thrombocytopenia (59000/mm3), neutropenia (500/mm3), hyperferritinemia $(6932 \mu \mathrm{g} / \mathrm{L})$ and hypertriglyceridemia $(743 \mathrm{mg} / \mathrm{dl})$ were observed. Microscopic evaluation of bone marrow aspiration biopsy showed megaloblastic changes. However, hemophagocytosis was not present. Based on laboratory and clinical findings, the patient met the criteria for HLH. Corticosteroids and cyclosporine treatment were given according to the HLH-2004 protocol. Etoposide was not given as EBV DNA was high (20634 copy/ml). The chimerism analysis was low $(6 \%)$, and the patient was given lymphocyte infusion from his EBV IgG positive donor for EBV reactivation. A second HSCT with conditioning regimen and interferon alpha- $2 b$ treatment was planned, but it could not be performed as the patient developed pneumonia. Candida inconspicua was isolated from bronchoalveolar lavage culture. Despite antifungal treatment, the pneumonia did not improve. Unfortunately, the patient died of respiratory insufficiency and multiorgan failure.

\section{Discussion}

DOCK2 deficiency is caused by compound heterozygous or homozygous mutations of the DOCK2 gene (Fig. 1). It is one of the rare CIDs reported in 11 patients. $^{4-6}$ Six out of 11 underwent HSCT (Table I). Three patients received myeloablative while one received reduced-intensity conditioning regimens. One patient underwent HSCT from the match related sibling without conditioning, and she was well. In case of severe viral infections in CID, it is difficult to decide to give a conditioning regimen to the patient. As he had a very low T-Cell Receptor Excision Circles (TREC) (1\% (31-81)) and T cell activation and had a history of severe cytomegalovirus (CMV) infection, we performed HSCT from his HLA-identical father without giving any conditioning regimen. After the diagnosis of DOCK2 deficiency, and due to the low level of chimerism, we planned a second HSCT. However, the patient died from EBV-associated secondary HLH and fungal pneumonia.

Patients with DOCK2 deficiency are highly prone to bacterial, viral, and fungal infections. Four out of the eleven patients previously reported died from infections (Table I). Two of the patients who died had multiple organ failures after varicella infection. The others died from recurrent CMV and Klebsiella infection and sepsis, respectively. The present patient had

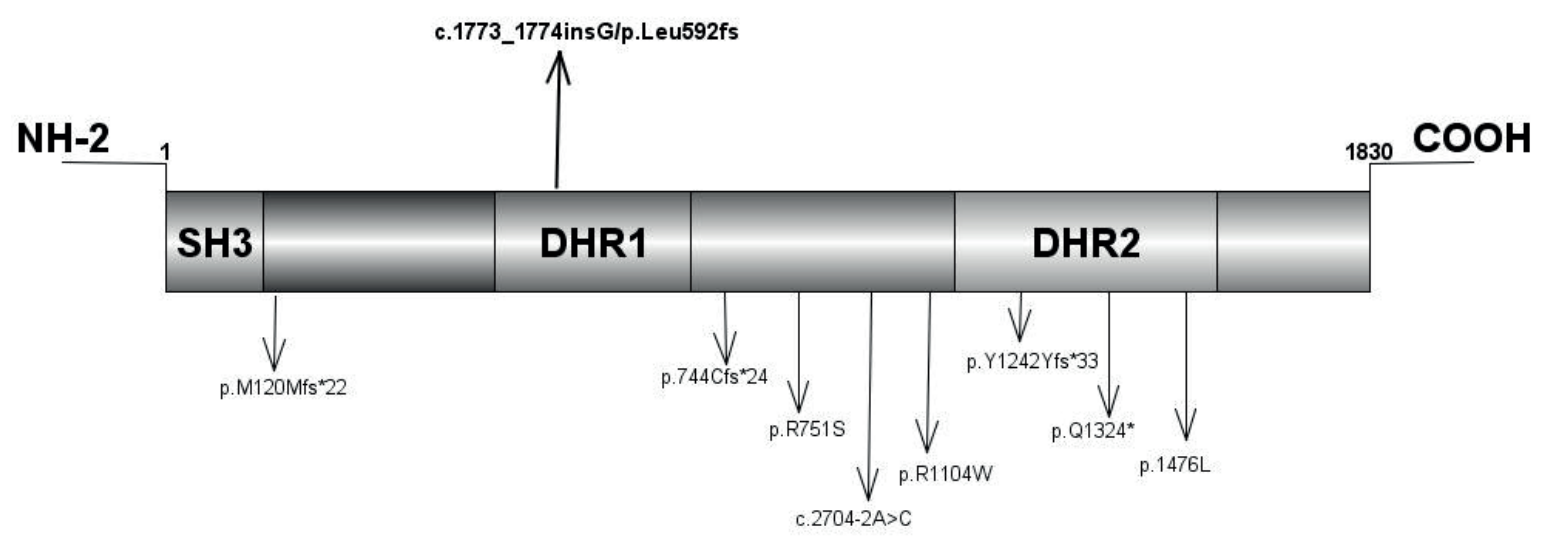

Fig. 1. Structure of DOCK2 protein showing the different domains and defined mutations. 
Table I. DOCK2 defective patients, review of the literature.

\begin{tabular}{|c|c|c|c|c|c|c|}
\hline Patients & $\begin{array}{l}\text { Dobbs et all. } \\
\text { P1 }\end{array}$ & $\begin{array}{l}\text { Dobbs et all. } \\
\text { P2 }\end{array}$ & $\begin{array}{l}\text { Dobbs et all. } \\
\text { P3 }\end{array}$ & $\begin{array}{l}\text { Dobbs et all. } \\
\text { P4 }\end{array}$ & $\begin{array}{l}\text { Dobbs et all. } \\
\text { P5 }\end{array}$ & $\begin{array}{l}\text { Moens et all. } \\
\text { P6 }\end{array}$ \\
\hline $\begin{array}{l}\text { DOCK2 } \\
\text { mutation }\end{array}$ & p.Y1242Yfs*33 & p.R1104W p.Q1324* & p.R751S & p.F744Cfs*27 & $\begin{array}{l}\text { p.M120Mfs*22 } \\
\text { p.P1476L }\end{array}$ & c. $2704-2 \mathrm{~A}>\mathrm{C}$ \\
\hline Ethnic origin & Lebanese & Finnish & Turkish & Turkish & Hispanic & Moroccan \\
\hline $\begin{array}{l}\text { Age at } \\
\text { evaluation }\end{array}$ & 5 months & 2.5 years & 6.3 years & 1 years & 4 months & One months \\
\hline Sex & Male & Female & Male & Male & Male & Male \\
\hline $\begin{array}{l}\text { Symptoms at } \\
\text { onset }\end{array}$ & $\begin{array}{l}\text { bronchiolitis caused } \\
\text { by } \\
\text { RSV }\end{array}$ & $\begin{array}{l}\text { granulomatous } \\
\text { inflammation in } \\
\text { lungs caused by } \mathrm{M} \text {. } \\
\text { avium intracellulare }\end{array}$ & $\begin{array}{l}\text { meningoencephalitis } \\
\text { caused by mumps }\end{array}$ & $\begin{array}{l}\text { sneonatal-onset } \\
\text { chronic diarrhea, } \\
\text { oral moniliasis }\end{array}$ & $\begin{array}{l}\text { İnterstitial } \\
\text { pneumonia }\end{array}$ & $\begin{array}{l}\text { Ulcerative perianal } \\
\text { dermatitis, E. coli } \\
\text { pyelonephritis }\end{array}$ \\
\hline $\begin{array}{l}\text { Other } \\
\text { symptoms and } \\
\text { findings }\end{array}$ & $\begin{array}{l}\text { recurrent } \\
\text { pneumoniae }\end{array}$ & $\begin{array}{l}\text { recurrent otitis } \\
\text { media, } \\
\text { pneumonia } \\
\text { and diarrhea, } \\
\text { recurrent } \\
\text { thrombocytopenia } \\
\text { and thrombosis }\end{array}$ & $\begin{array}{l}\text { recurrent upper and } \\
\text { respiratory tract } \\
\text { infection }\end{array}$ & $\begin{array}{l}\text { growth failure, } \\
\text { hepatomegaly }\end{array}$ & Rectal fistula & $\begin{array}{l}\text { nephrotic syndrome, } \\
\text { Omenn Syndrome }\end{array}$ \\
\hline $\begin{array}{l}\text { Viral } \\
\text { infections }\end{array}$ & RSV & $\begin{array}{l}\text { M. avium } \\
\text { intracellulare }\end{array}$ & Mumps, Varicella & $\begin{array}{l}\text { parainfluenza } \\
\text { virüs, type } 3 \\
\text { adenovirus, CMV, K. } \\
\text { pneumoniae }\end{array}$ & & - \\
\hline HSCT & + & + & - & - & + & - \\
\hline Donor & MMRD & MUD & & & MRD & \\
\hline $\begin{array}{l}\text { Conditioning } \\
\text { regimen }\end{array}$ & $\begin{array}{l}\text { myeloablative } \\
\text { conditioning with } \\
\text { busulfan and } \\
\text { fludarabine }\end{array}$ & $\begin{array}{l}\text { reduced-intensity } \\
\text { conditioning } \\
\text { with treosulfan, } \\
\text { fludarabine, and } \\
\text { alemtuzumab }\end{array}$ & & & $\begin{array}{l}\text { Myeloablative } \\
\text { conditioning with } \\
\text { busulfan and } \\
\text { cyclophosphamide }\end{array}$ & \\
\hline Cause of death & Alive & Alive & Varicella pneumonia & $\begin{array}{l}\text { Sepsis } \\
\text { (K.pneumoniae) }\end{array}$ & Alive & $\begin{array}{l}\text { ARDS and capillary } \\
\text { leak syndrome }\end{array}$ \\
\hline
\end{tabular}

ATG: anti-thymocyte globulin, GVHD: graft versus host disease, HSCT: hematopoietic stem cell transplantation, MMRD: mismatched related donor, MRD; matched related donor, MUD: matched unrelated donor, NA: not available

early-onset severe CMV infection. After HSCT, he suffered from EBV-associated secondary HLH and died from Candida pneumonia. In this case, IVIG was started even though immunoglobulin levels were normal. Because the patient's clinical and immunological features were compatible with severe combined immunodeficiency.

HLH is a rare and highly fatal multisystem inflammatory syndrome. HLH is common in patients with primary immunodeficiencies, particularly those with abnormal $\mathrm{T}$ cell functions. However, secondary HLH after transplantation in PID is uncommon. ${ }^{8,9}$ Asano et al. ${ }^{10}$ reported that secondary HLH developed in 37 out of 5427 HSCT cases, and four out of 37 were PID. Ali et al. ${ }^{11}$ reported EBV-associated HLH in three out of 408 patients who underwent allogeneic HSCT, and all three patients died. Epstein-Barr virus is the most frequently associated infectious agent with HLH. ${ }^{11}$ In these cases, it is challenging to control HLH and EBV. ${ }^{10}$ Therefore, EBV titer monitoring is needed in the patients before and after the HSCT. In the present case, the HLH2004 protocol was given without etoposide, because of high EBV DNA copy numbers (20634 copy/ml). Anti-CD20 antibody (rituximab) improves outcomes in patients with EBVassociated lymphoproliferative disorders by depleting B cells. ${ }^{12}$ However, we could not give the patient the rituximab therapy. Because the patient's fever persisted, and we could not rule out sepsis. HLH could have possibly occurred in the patient due to graft failure.

In plasmacytoid dendritic cells, induction of type I interferons (IFN) critically depends on 
Table I. Continued.

\begin{tabular}{|c|c|c|c|c|c|c|}
\hline Patients & $\begin{array}{l}\text { Moens et all. } \\
\text { P7 }\end{array}$ & $\begin{array}{l}\text { Moens et all. } \\
\text { P8 }\end{array}$ & $\begin{array}{l}\text { Moens et all. } \\
\text { P9 }\end{array}$ & $\begin{array}{l}\text { Alosaimi et all. } \\
\text { P10 }\end{array}$ & $\begin{array}{l}\text { Alosaimi et all. } \\
\text { P11 }\end{array}$ & $\begin{array}{l}\text { Our patient } \\
\text { P12 }\end{array}$ \\
\hline $\begin{array}{l}\text { DOCK2 } \\
\text { mutation }\end{array}$ & c. $2704-2 \mathrm{~A}>\mathrm{C}$ & c. $2704-2 \mathrm{~A}>\mathrm{C}$ & c. $2704-2 \mathrm{~A}>\mathrm{C}$ & Del 902-1078 & Phe848fs & p.L592Afs*76 \\
\hline Ethnic origin & Moroccan & Moroccan & Moroccan & NA & NA & Turkish \\
\hline $\begin{array}{l}\text { Age at } \\
\text { evaluation }\end{array}$ & NA & NA & NA & 2 weeks of age & 5 months & 16 months \\
\hline Sex & Female & Male & Female & & & Male \\
\hline $\begin{array}{l}\text { Symptoms at } \\
\text { onset }\end{array}$ & & NA & NA & $\begin{array}{l}\text { chronic diarrhea, } \\
\text { recurrent } \\
\text { sinopulmonary } \\
\text { infection, CMV } \\
\text { viremia }\end{array}$ & $\begin{array}{l}\text { chronic diarrhea, } \\
\text { recurrent } \\
\text { pneumonia, oral } \\
\text { candidiasis }\end{array}$ & recurrent diarrhea \\
\hline $\begin{array}{l}\text { Other } \\
\text { symptoms and } \\
\text { findings }\end{array}$ & & NA & NA & - & NA & $\begin{array}{l}\text { perianal abscess, } \\
\text { recurrent } \\
\text { pneumonia, Growth } \\
\text { retardation, EBV } \\
\text { associated HLH }\end{array}$ \\
\hline $\begin{array}{l}\text { Viral } \\
\text { infections }\end{array}$ & Varicella & NA & NA & CMV & - & $\begin{array}{l}\text { CMV, EBV, Candida } \\
\text { inconspicua }\end{array}$ \\
\hline HSCT & - & + & + & + & - & + \\
\hline Donor & NA & NA & MRD & MUD & & MRD \\
\hline $\begin{array}{l}\text { Conditioning } \\
\text { regimen }\end{array}$ & & NA & $\begin{array}{l}\text { Without } \\
\text { conditioning }\end{array}$ & $\begin{array}{l}\text { myeloablative } \\
\text { conditioning } \\
\text { with busulfan, } \\
\text { fludarabine, and } \\
\text { ATG }\end{array}$ & & $\begin{array}{l}\text { Without } \\
\text { conditioning }\end{array}$ \\
\hline Cause of death & Varicella infection & $\begin{array}{l}\text { Alveolar } \\
\text { hemorrhage after } \\
\text { HSCT }\end{array}$ & Alive & Alive & Sepsis & GVHD Pneumoniae \\
\hline
\end{tabular}

ATG: anti-thymocyte globulin, GVHD: graft versus host disease, HSCT: hematopoietic stem cell transplantation, MMRD: mismatched related donor, MRD; matched related donor, MUD: matched unrelated donor, NA: not available

IFN regulatory factor 7 (IRF-7) and IkappaB Kinase IKK $\alpha$, which activates IRF-7 after binding. ${ }^{13}$ In DOCK2-/- plasmacytoid dendritic cells, phosphorylation of IKK- $\alpha$ and nuclear translocation of Interferon Regulatory Factors (IRF-7) were impaired, resulting in a selective loss of IFN- $\alpha /$ IFN- $\beta$ induction. Recombinant IFN- $\alpha 2 b$ replacement protects DOCK 2 deficient fibroblasts from virus-induced cell death. During the HLH process, we planned to give interferon-alpha $2 \mathrm{~b}$ treatment to the patient. However, we could not give as we lost the patient within a few days.

In conclusion, DOCK2 deficiency is a rare form of CID. Its diagnosis is challenging because these patients may have normal lymphocyte count on routine laboratory analysis. Accurate diagnosis usually requires genetic testing, and early diagnosis may increase the chance of effective treatment. The curative treatment should be HSCT soon after diagnosis. Further studies are needed to define other treatment options for DOCK2 deficient patients.

\section{Author contribution}

The authors confirm contribution to the paper as follows: study conception and design: ESA, DC, IT; data collection: ESA, IB; analysis and interpretation of results: CT, BC, DC; draft manuscript preparation: ESA, DC, İT. All authors reviewed the results and approved the final version of the manuscript.

\section{Conflict of interest}

The authors declare that they have no conflict of interest. 


\section{REFERENCES}

1. Gotoh K, Tanaka Y, Nishikimi A, et al. Differential requirement for DOCK2 in migration of plasmacytoid dendritic cells versus myeloid dendritic cells. Blood 2008; 111: 2973-2976. https:// doi.org/10.1182/blood-2007-09-112169

2. Nishikimi A, Kukimoto-Niino M, Yokoyama S, Fukui Y. Immune regulatory functions of DOCK family proteins in health and disease. Exp Cell Res 2013; 319: 2343-2349. https://doi.org/10.1016/j. yexcr.2013.07.024

3. Sanui T, Inayoshi A, Noda M, et al. DOCK2 is essential for antigen-induced translocation of TCR and lipid rafts, but not PKC- $\theta$ and LFA-1, in T cells. Immunity 2003; 19: 119-129. https://doi.org/10.1016/ S1074-7613(03)00169-9

4. Moens L, Gouwy M, Bosch B, et al. Human DOCK2 deficiency: report of a novel mutation and evidence for neutrophil dysfunction. J Clin Immunol 2019; 39: 298-308. https://doi.org/10.1007/s10875-019-00603-w

5. Dobbs K, Domínguez Conde C, Zhang SY, et al. Inherited DOCK2 deficiency in patients with earlyonset invasive infections. N Engl J Med 2015; 372: 2409-2422. https://doi.org/10.1056/NEJMoa1413462

6. Alosaimi MF, Shendi H, Beano A, et al. T cell mitochondrial dysfunction and lymphopenia in DOCK2-deficient patients. J Allergy Clin Immunol 2019; 144: 306-309. https://doi.org/10.1016/j. jaci.2019.02.020

7. Richards S, Aziz N, Bale S, et al. Standards and guidelines for the interpretation of sequence variants: a joint consensus recommendation of the American College of Medical Genetics and Genomics and the Association for Molecular Pathology. Genet Med 2015; 17: 405-423. https://doi.org/10.1038/ $\operatorname{gim} .2015 .30$
8. Faitelson Y, Grunebaum E. Hemophagocytic lymphohistiocytosis and primary immune deficiency disorders. Clin Immunol 2014; 155: 118125. https://doi.org/10.1016/j.clim.2014.09.008

9. Sinno MG, Rosen D, Wittler R. Concomitant presentation of hemophagocyticlymphohistiocytosis and posttransplant lymphoproliferative disease-like lymphoma in a mildly immunosuppressed leukemia patient: an unusual association. Pediatr Blood Cancer 2016; 63: 1474-1476. https://doi.org/10.1002/ pbc. 26033

10. Asano T, Kogawa K, Morimoto A, et al. Hemophagocytic lymphohistiocytosis after hematopoietic stem cell transplantation in children: a nationwide survey in Japan. Pediatr Blood Cancer 2012; 59: 110-114. https://doi.org/10.1002/pbc.23384

11. Ali S, AlThubaiti S, Renzi S, et al. Hemophagocytic lymphohistiocytosis is a sign of poor outcome in pediatric Epstein-Barr virus-associated posttransplant lymphoproliferative disease after allogeneic hematopoietic stem cell transplantation. Pediatr Transplant 2019; 23: e13319. https://doi. org/10.1111/petr.13319

12. Chellapandian D, Das R, Zelley K, et al. Treatment of Epstein Barr virus-induced haemophagocytic lymphohistiocytosis with rituximab-containing chemo-immunotherapeutic regimens. Br J Haematol 2013; 162: 376-382. https://doi.org/10.1111/bjh.12386

13. Gotoh K, Tanaka Y, Nishikimi A, et al. Selective control of type I IFN induction by the Rac activator DOCK2 during TLR-mediated plasmacytoid dendritic cell activation. J Exp Med 2010; 207: 721730. https://doi.org/10.1084/jem.20091776 